\title{
Development of a control alternative for the citrus fruit borer, Ecdytolopha aurantiana (Lepidoptera, Tortricidae): from basic research to the grower
}

\author{
José Roberto P. Parra ${ }^{1}$, José Maurício S. Bento ${ }^{1}$, Mauro S. Garcia ${ }^{2}$, Pedro T. Yamamoto ${ }^{3}$, \\ Evaldo F. Vilela ${ }^{4} \&$ Walter S. Leal ${ }^{5}$
}

\begin{abstract}
${ }^{1}$ Departamento de Entomologia, Fitopatologia e Zoologia Agrícola, ESALQ/USP. Caixa Postal 09, 13418-900 Piracicaba-SP, Brazil. E-mail:jrpparra@esalq.usp.br

${ }^{2}$ Departamento de Fitossanidade, Universidade Federal de Pelotas. Campus Universitário s/n. 96010-900 Pelotas-RS, Brazil.

${ }^{3}$ Fundo de Defesa da Citricultura, Fundecitrus. Av. Adhemar Pereira de Barros 201. 14807-040 Araraquara-SP, Brazil.

${ }^{4}$ Departamento de Biologia Animal, Universidade Federal de Viçosa. 36571-000, Viçosa-MG, Brazil.

${ }^{5}$ Department of Entomology, University of California. 95616, Davis-CA, USA.
\end{abstract}

\begin{abstract}
Resumo. Desenvolvimento de uma alternativa de controle para o bicho-furão-dos-citros, Ecdytolopha aurantiana (Lepidoptera, Tortricidae): da pesquisa básica ao produtor. São descritas todas as etapas da pesquisa, desenvolvidas de 1995 a 2000, para a síntese do feromônio sexual de Ecdytolopha aurantiana (Lima, 1927), visando ao monitoramento desta praga que causa perdas da ordem de 50 milhões de dólares ao ano à citricultura paulista. As pesquisas básicas são apresentadas, incluindo o desenvolvimento de uma dieta artificial para o inseto, estudo de suas exigências térmicas e hídricas, estudos comportamentais, síntese da substância atraente para o macho desde a formulação até a distribuição do feromônio ao agricultor, e a sua comercialização. Trata-se de um caso de sucesso, a um custo de 50 mil dólares, com pesquisas inter- e multidisciplinares e que pode ser adotado para outros insetos-praga do país.
\end{abstract}

Palavras-Chave. Biologia; citros; controle biológico; feromônio sexual; manejo integrado de pragas.

Abstract. All research steps, developed from 1995 to 2000, to synthesize the sex pheromone of Ecdytolopha aurantiana (Lima, 1927) are described, in order to monitoring this pest that causes losses in the order of 50 million dollars per year to citriculture in the State of São Paulo. The basic researches conducted are described, including the development of an artificial diet for the insect, the study of its temperature and humidity requirements, behavioral studies, and synthesis of the male-attracting substance up to the formulation and distribution of the pheromone to the grower, by means of its commercialization. It is a case of success, at a cost of 50 thousand dollars, involving inter- and multidisciplinary researches, which can be adopted to other insect pests in the country.

KEYwords. Biological control; biology; Citrus; integrated pest management; sex pheromone.

Citriculture is significantly important in the Brazilian economy, since it represents a revenue of over 1.5 billion dollars annually, translating into hard currency for the country (AnONimous 2000a). The State of São Paulo alone concentrates about $85 \%$ of the Brazilian citrus production (FNP 2001).

Citruses are attacked by many pests and diseases, demanding expenditures in the order of 160 million dollars to control them, to avoid what sometimes can develop into total loss (AnONymous 2000a). The arthropods that comprise the harmful entomofauna in this crop include mite species, fruit flies, scale insects and, in recent years, insect-transmitted diseases such as citrus variegated chlorosis (CVC), associated with leafhoppers, citrus canker, which had its importance increased with the introduction of the citrus leaf miner in 1996 in Brazil, and sudden death, a recent problem which is probably also associated with insects, such as aphids (PARRA et al. 2003).

The need to control all of the above-mentioned pests with agrochemicals, without the adoption of a suitable crop management criterion, led to the indiscriminate use of these products, which favored the appearance of new pests in orange groves. This was the case with the citrus fruit borer,
Ecdytolopha aurantiana (Lima, 1927) (Lepidoptera: Tortricidae), toward the end of the 1980's, when it achieved key-pest status from a former secondary-pest rank. By directly attacking the fruit, this insect renders them worthless for fresh consumption and for processing, as a result of shedding and rotting.

Losses to the fruit borer E. aurantiana have become increasingly higher, reaching damages in the order of 50 million dollars per year in the 1990's in the State of São Paulo (ANONYMOUs 2000b). For the citrus producers, these losses corresponded to 1 to 2 boxes of fruits per plant in more intensely-attacked localities (Pinto 1994, 1995; Prates \& PinTO 1988a, b, 1991).

At that time, this pest began to be controlled with agrochemicals in a wrong manner, i.e., when the first attacked fruits were observed, which in most instances did not control the pest and eliminated natural enemies, increasing losses. Thus, basic studies about the pest were needed in order to rationalize its control, based on biological, ecological and behavioral knowledge about the insect to establish a practical and efficient control measure that could be used by the citrus grower. 
The objective of this work is to describe the steps that were developed to rationalize $E$. aurantiana control, from the basics up to a final product that is currently sold to citrus producers. This project was conducted during a period of 4-5 years (1995 to 2000), in an inter- and multidisciplinary program that could provide a model for other important agricultural pests in Brazil. The organizations involved were Universidade de São Paulo (USP), by means of Escola Superior de Agricultura Luiz de Queiroz (ESALQ), Universidade Federal de Viçosa (UFV), the National Institute of Sericultural and Entomological Science (NISES, Tsukuba, Japan), University of CaliforniaDavis (USA), Fuji Flavor Co. (Japan), with financial support from Fundo de Defesa da Citricultura (Fundecitrus Citriculture Defense Fund).

\section{TAXONOMIC IDENTIFICATION}

The first step (as the studies began) consisted in the correct identification of the pest. The citrus fruit borer, until then known as Gymnandrosoma aurantianum Lima, 1927 (GALlo et al. 1988), was correctly identified as Ecdytolopha aurantiana (Lima, 1927) (Lepidoptera, Tortricidae, Olethreutinae) by Dr. Vitor Osmar Becker in the beginning of the research (1994).

\section{ARTIFICIAL DIET AND BASIC BIOLOGY STUDIES IN LABORATORY}

The next step consisted in developing an artificial diet that would allow the pest to be continually maintained throughout the year in the laboratory (Table I) (Garcia \& Parra 1999).

This diet was essential for the success of the entire program, in view of the difficulty of rearing this insect on natural diet (orange fruits). Only after developing this diet could the studies on biology and behavior of the citrus fruit borer be conducted. Until then, no knowledge was available on the several developmental stages of the pest, its number of instars (4), survival and duration of the egg, larva, and pupal stages, as well as adult longevity and their egg-laying capacity (Tables II and III); fertility life table studies $(\lambda=1.0629)$, in addition to sex dimorphism characterization of larvae, pupae, and adults also allowed great advances in the bioecological studies (GARCIA 1998).

\section{FACTORS THAT AFFECT THE PEST IN THE FIELD}

Once the basic studies in the laboratory were concluded, the researches on factors that affect the pest's populations under field conditions were initiated.

Use of agrochemicals versus natural enemies. The haphazard application of insecticides in citrus groves during the 1980 's, especially pyrethroids sprayed by the hot fogging system, contributed to eliminate natural enemies, including parasitoids and predators. This resulted in biological disruptions in the citrus groves, favoring pest population increases, especially with respect to the fruit borer. There was

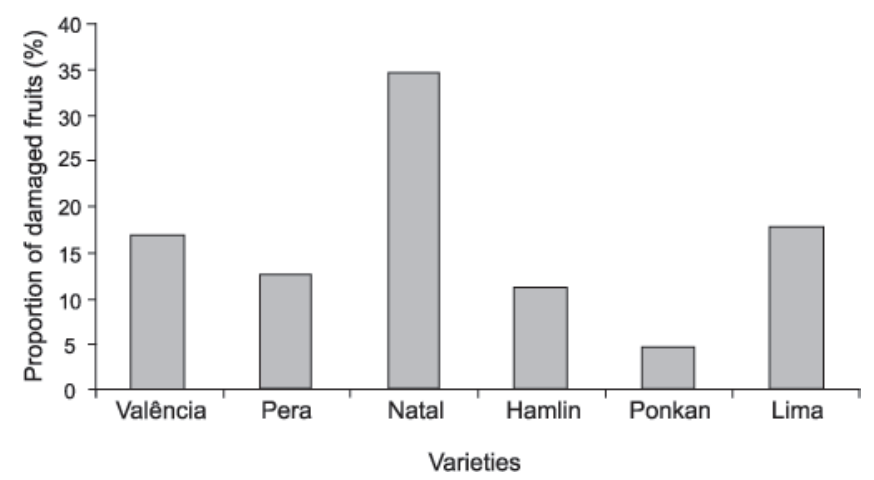

Fig. 1. Damaged orange fruits (\%) by the citrus fruit borer, Ecdytolopha aurantiana, on different citrus varieties (Adapted from GARCIA 1998).

probably a significant reduction of the braconid Hymenochaonia delicate (Cresson, 1872) (Hymenoptera, Braconidae), one of the most frequently-encountered parasitoids attacking this pest, which parasitizes third-instar larvae and emerges from the pest's pupae. During certain seasons of the year, without application of agrochemicals, natural parasitism can reach 56.4\% (GARCIA et al. 1998). Another parasitoid that can be potentially used is Trichogramma spp. (Hymenoptera, Trichogrammatidae), which parasitizes the pest's eggs and has been studied only more recently, thanks to the citrus management advancements that have been achieved (GarCia 1998; Molina 2003). However, the incorrect application of agrochemicals can lead to its destruction.

Grove location. The initial attack of the fruit borer depends on the geographical situation of the grove. In general, attacks begin next to wooded areas, where $E$. aurantiana probably finds a variety of wild hosts, since it is known to occur in guava, lychee, mango (Silva et al. 1968), macadamia (White \& Tuck 1993), and custard apple trees (NAKANO \& SoARES 1995), in addition to citrus. In other countries, it is also referred to occur on banana and coconut (MEYRICK 1931), cherimoya (Schultz 1939), Simaruba amara (bitter ash) fruits (Simarubaceae) (FenNAh 1942), and on western soapberry (Sapindus saponaria) (Sapindaceae) (Whiте 1999).

Fruit maturation stage. In small populations, the pest shows a marked preference for ripe fruits. However, when the population increases, it will attack green and mature fruits without distinction, even though duration and mortality of the larval stage have a tendency to increase on green fruits (lower $\mathrm{pH}$ values). According to PARRA et al. (2001a), larval duration is between 24 and 17 days on green fruits $(\mathrm{pH} 2.5$ to 3.0 ) with a viability between 46 and $68 \%$. On the other hand, larval duration on ripe fruits ( $\mathrm{pH} 4.6$ to 5.1) is between 16 and 16.5 days with 74 to $85 \%$ viability. Therefore, the fruit maturation stage affects the larval development of E. aurantiana. Nevertheless, it is worth pointing out that even having their development impaired on more acid fruits, the larvae are still 


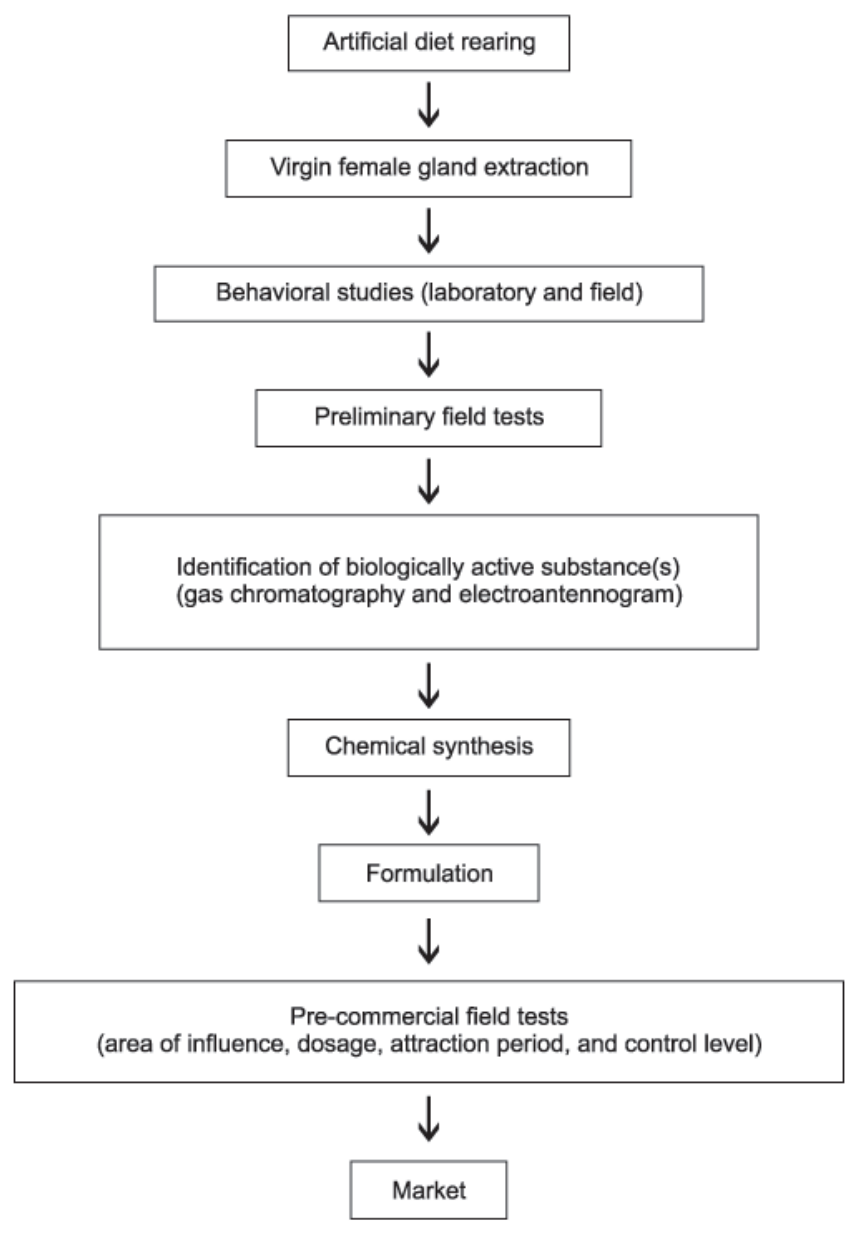

Fig. 2. Steps to obtain the sex pheromone of citrus fruit borer, Ecdytolopha aurantiana.

able to penetrate them. Also, in spite of dying in great numbers at the very initial instars, they still cause considerable damage, leading to rotting and to the total loss of the perforated fruits.

Temperature and relative humidity. Temperature and $\mathrm{RH}$ play an important role on fruit borer duration and viability. Thus, the effect of temperature on the insect's development was studied (Table IV), and based on these and on temperature requirement results (Table $\mathrm{V}$ ), the number of pest generations for the State of São Paulo was established, varying from 7.1 generations in Limeira to 8.3 in Barretos, with 7.2 generations in Araraquara; 7.3 in Bebedouro; and 8.2 in São José do Rio Preto (GARCIA 1998). RH affects especially the egg-laying capacity and longevity of $E$. aurantiana males and females. In drier periods, the insect does not lay eggs and has a shorter life (Table VI).

Soil moisture. Soil moisture could be important as well, because $78 \%$ of pupations, on average, occur in the soil. Saturated soils are unfavorable for the pest's emergence; viability tends to decrease in dry soils, and soils with an intermediate moisture are the most suitable (PARRA, J. R. P. personal observation).

Varieties. The citrus variety used can promote pest population increases, because the attack depends on the species that is present in the grove, although the pest can occur without distinction on all varieties (Fig. 1).

Penetration in the fruit. After eclosion, the first-instar fruit borer larva takes, on average, 3 hours and 40 minutes to penetrate into the fruit, with an interval between 2 and 7 hours (CARVAlho 2003). The same author demonstrated that after 48 hours, about $50 \%$ of the small larvae reach the pulp, and that mortality at this stage can reach $32 \%$. In this case, mortality could be strongly associated with fruit $\mathrm{pH}$ at the time of penetration, as previously mentioned.

Market and Industrial Processing. The market price is another factor responsible for the pest's evolution. Thus, in years when prices are lower, citrus growers often do not harvest, or only harvest to some incomplete extent. These sites will constitute future infestation foci for neighboring groves. Similarly, late harvesting to meet juice industry needs could be another reason for the occurrence of lingering foci of infestation in the field.

\section{FRUIT BORER BEHAVIOR}

Based on the assumption that the chemical control of $E$. aurantiana, as performed in the past, i.e., calculated on a certain percentage of attacked fruits (GRAVENA 1998) was inefficient to adequately control the pest, since in this case the attacked fruits would be already damaged, and the larvae present inside the fruits would not be reached by the chemicals, another alternative was sought. The conclusion was that a more objective monitoring should be developed, in order to anticipate the occurrence of this pest in the grove. Thus, since the egg

Table I. Diet used for rearing the citrus fruit borer, Ecdytolopha aurantiana, in the laboratory (GARCIA \& PARRA 1999).

\begin{tabular}{lc}
\hline \multicolumn{1}{c}{ Ingredients } & Amount \\
\hline Bean & $75.00 \mathrm{~g}$ \\
Wheat germ & $60.00 \mathrm{~g}$ \\
Soybean protein & $30.00 \mathrm{~g}$ \\
Casein & $30.00 \mathrm{~g}$ \\
Brewer's yeast & $37.50 \mathrm{~g}$ \\
Vitamin solution & $9.00 \mathrm{ml}$ \\
Ascorbic acid & $3.60 \mathrm{~g}$ \\
Sorbic acid & $1.80 \mathrm{~g}$ \\
Methyl parahydroxybenzoate (Nipagin) & $3.00 \mathrm{~g}$ \\
Tetracycline & $113.00 \mathrm{mg}$ \\
Formaldehyde (40\%) & $3.60 \mathrm{ml}$ \\
Agar & $23.00 \mathrm{~g}$ \\
Distilled water & $1200 \mathrm{ml}$ \\
\hline
\end{tabular}


Table II. Duration and mean viability ( \pm SEM) for the egg, larva, and pupal stages, and biological cycle (egg-adult) of the citrus fruit borer, Ecdytolopha aurantiana, reared on artificial diet and on "Pera" and "Natal" orange fruits. Temp. $27 \pm 2{ }^{\circ} \mathrm{C}$, RH $60 \pm 10 \%$ and 14 -h photophase (Adapted from GarCIA 1998).

\begin{tabular}{lcccccc}
\hline & \multicolumn{2}{c}{ Artificial Diet } & \multicolumn{2}{c}{ "Pera" Orange Fruits } & \multicolumn{2}{c}{ "Natal" Orange Fruits } \\
\hline Stages/Period & $\begin{array}{c}\text { Duration } \\
\text { (days) }\end{array}$ & $\begin{array}{c}\text { Viability } \\
(\%)\end{array}$ & $\begin{array}{c}\text { Duration } \\
(\text { days })\end{array}$ & $\begin{array}{c}\text { Viability } \\
(\%)\end{array}$ & $\begin{array}{c}\text { Duration } \\
(\text { days })\end{array}$ & $\begin{array}{c}\text { Viability } \\
(\%)\end{array}$ \\
\hline Egg & $5.0 \pm 0.1$ & $71.4 \pm 7.0$ & $5.0 \pm 0.1$ & $71.4 \pm 7.0$ & $5.0 \pm 0.1$ & $71.4 \pm 7.0$ \\
Larva & $12.6 \pm 0.2$ & $93.3 \pm 2.2$ & $21.7 \pm 0.3$ & 100.0 & $18.3 \pm 0.5$ & 100.0 \\
Pupa & $11.4 \pm 0.1$ & $86.0 \pm 3.5$ & $9.6 \pm 0.2$ & $81.1 \pm 4.8$ & $9.6 \pm 0.2$ & $84.7 \pm 6.9$ \\
Biological cicle & $32.8 \pm 0.2$ & $71.2 \pm 3.4$ & $39.7 \pm 0.6$ & $60.3 \pm 5.4$ & $35.8 \pm 0.4$ & $68.3 \pm 9.1$ \\
\hline
\end{tabular}

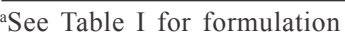

stage could not be considered as a sampling unit, because it is difficult to visualize in the field, and because the eggs could be mistaken for other pests, the efforts focused on the adult stage for a monitoring strategy.

Diurnal and nocturnal activity. During the day, the fruit borer adults are not very visible on the plant, since they remain motionless and are mimetic on branches. Field studies have shown that during this period the adults remain a good part of the time on leaves $(92.6 \%)$; fruits $(4.7 \%)$; and branches $(2.7 \%)$ (Bento et al. 2001a). After dusk, E. aurantiana begins its egglaying and mating activities, described ahead.

Egg-laying site and time. The adults have a marked preference for laying their eggs at heights between 1 and $2 \mathrm{~m}$, thus characterizing this site in the plant as preferential for attack (GARCIA 1998).

The egg-laying time in the field or in the laboratory is mainly at dusk, providing an indication that the adults are more active at this time. This observation favored the recommendation, when necessary, of the most suitable time for applying agrochemicals, considering that the adults would be more exposed to the action of the products.

It was verified that oviposition on fruits is possibly mediated by chemical factors, since there is a strong tendency for the females to lay a single egg per fruit, regardless of variety, indicating that some chemical marker is added after the egg is laid, inhibiting other females from laying their eggs on that fruit.

Mating. By marking males and females with fluorescent powder, it was verified that mating in E. aurantiana occurs about $1 \mathrm{~h}$ after dusk, with a duration of 1 to $4 \mathrm{~h}$ ( $2 \mathrm{~h}$ on average) (BENTo et al. 2001a). In the same study, it was also observed that matings always occurred at the upper third of the plant in $100 \%$ of the cases, regardless of plant height or age.

Verification of the fruit borer's time and site of mating were indispensable for the subsequent stages of the project. Based on this information, a sequence of laboratory and field studies culminated in the identification and obtaining of the synthetic sex pheromone for the species (Fig. 2).
In the case of $E$. aurantiana, this pheromone is produced by the female, and consists of a major compound, $(E)-8$ dodecenyl acetate (E8-12:Ac), and an alcohol as minor compound, known as (E)-8-dodecenol (E8-12:OH) (LEAL et al. 2001).

\section{PRACTICAL USE}

After synthesizing the pheromone in the form of a tablet, it was necessary to establish the control level. To that effect, a correlation was established between the number of insects captured in the trap and the loss of fruit in the grove. These results indicated the best moment for the actual control to be iniciated. In addition, the area of influence and period of attraction of the sex pheromone in the field were also established (BENTO et al. 2001b).

Therefore, based on these researches, five steps for its use under field conditions were defined (PARRA et al. 2001b):

(1) Placing the trap in the upper third of the plant, regardless of height or age (mating site); (2) changing the set (trap + pheromone) every 30 days; (3) learning to recognize the fruit borer adult captured in the trap; (4) counting and eliminating the insects from the trap once a week, establishing the control

Table III. Duration of the pre-oviposition and oviposition periods, fecundity, longevity of males and females, pupal weight, and sex ratio of the citrus fruit borer, Ecdytolopha aurantiana, reared on artificial diet. Temp. $27 \pm 2{ }^{\circ} \mathrm{C}$, RH $60 \pm 10 \%$ and 14-h photophase (Adapted from GARCIA 1998).

\begin{tabular}{llc}
\hline Biological parameters & & Mean ( \pm SEM) \\
\hline Pre-oviposition (days) & & 2 to 3 \\
Oviposition (days) & & $11.2 \pm 0.8$ \\
Fecundity & & $198.3 \pm 32.5$ \\
& Male & $20.4 \pm 1.6$ \\
Longevity (days) & Female & $26.1 \pm 1.2$ \\
& & \\
Pupal weight (mg) & Male & $23.9 \pm 0.4$ \\
Sex ratio & Female & $33.1 \pm 0.5$ \\
\hline
\end{tabular}


Table IV. Duration (days) and viability (\%) for the egg, larva, and pupal stages, and biological cycle (egg-adult) of E. aurantiana, reared on artificial diet and on different temperatures. RH: $60 \pm 10 \%$; photophase:14 hours (Adapted from GARCIA 1998).

\begin{tabular}{|c|c|c|c|c|c|c|c|c|}
\hline \multirow[b]{2}{*}{$\begin{array}{c}\text { Temperature } \\
\left({ }^{\circ} \mathrm{C}\right)\end{array}$} & \multicolumn{2}{|c|}{ Egg } & \multicolumn{2}{|c|}{ Larva } & \multicolumn{2}{|c|}{ Pupa } & \multicolumn{2}{|c|}{ Egg-Adult } \\
\hline & $\begin{array}{l}\text { Duration } \\
\text { (days) }\end{array}$ & $\begin{array}{c}\text { Viability } \\
(\%)\end{array}$ & $\begin{array}{l}\text { Duration } \\
\text { (days) }^{1}\end{array}$ & $\begin{array}{c}\text { Viability } \\
(\%)\end{array}$ & $\begin{array}{c}\text { Duration } \\
\text { (days) }\end{array}$ & $\begin{array}{l}\text { Viability } \\
(\%)^{2}\end{array}$ & 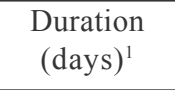 & $\begin{array}{c}\text { Viability } \\
(\%)^{3}\end{array}$ \\
\hline 18 & $\begin{array}{c}10,6 \pm 0,1 \mathrm{a} \\
(10-11)\end{array}$ & $76,3 \pm 9,4 \mathrm{a}$ & $\begin{array}{c}30,6 \pm 0,5 a \\
(25-49)\end{array}$ & $78,0 \pm 4,5 \mathrm{a}$ & $\begin{array}{c}20,9 \pm 0,2 \mathrm{a} \\
(13-25)\end{array}$ & $76,6 \pm 5,7 \mathrm{a}$ & $\begin{array}{c}61,8 \pm 0,5 \mathrm{a} \\
(55-76)\end{array}$ & $45,7 \mathrm{a}$ \\
\hline 20 & $\begin{array}{c}8,1 \pm 0,1 b \\
(8-10)\end{array}$ & $83,7 \pm 4,5 \mathrm{a}$ & $\begin{array}{c}30,3 \pm 0,5 a \\
(26-46)\end{array}$ & $79,0 \pm 5,1 \mathrm{a}$ & $\begin{array}{c}18,0 \pm 0,2 b \\
(14-21)\end{array}$ & $83,5 \pm 4,4 \mathrm{a}$ & $\begin{array}{c}56,5 \pm 0,6 b \\
(51-79)\end{array}$ & $55,2 \mathrm{a}$ \\
\hline 22 & $\begin{array}{c}7,3 \pm 0,1 \mathrm{c} \\
(7-9)\end{array}$ & $83,8 \pm 5,5 \mathrm{a}$ & $\begin{array}{c}25,9 \pm 0,3 b \\
(21-39)\end{array}$ & $86,0 \pm 4,6 \mathrm{a}$ & $\begin{array}{c}17,2 \pm 0,2 \mathrm{c} \\
(14-21)\end{array}$ & $84,8 \pm 5,2 \mathrm{a}$ & $\begin{array}{c}50,2 \pm 0,4 c \\
(43-61)\end{array}$ & $61,1 \mathrm{a}$ \\
\hline 25 & $\begin{array}{c}4,8 \pm 0,1 \mathrm{~d} \\
(4-7)\end{array}$ & $93,8 \pm 3,1 \mathrm{a}$ & $\begin{array}{c}18,8 \pm 0,3 \mathrm{c} \\
(16-25)\end{array}$ & $77,5 \pm 5,7 \mathrm{a}$ & $\begin{array}{c}11,8 \pm 0,1 \mathrm{~d} \\
(10-14)\end{array}$ & $80,6 \pm 5,5 \mathrm{a}$ & $\begin{array}{c}35,3 \pm 0,4 \mathrm{~d} \\
(30-45)\end{array}$ & $58,6 \mathrm{a}$ \\
\hline 28 & $\begin{array}{c}4,3 \pm 0,2 \mathrm{e} \\
(4-6)\end{array}$ & $95,2 \pm 4,8 \mathrm{a}$ & $\begin{array}{c}13,9 \pm 0,2 \mathrm{e} \\
(11-22)\end{array}$ & $69,0 \pm 6,1 \mathrm{a}$ & $\begin{array}{c}9,5 \pm 0,1 \mathrm{e} \\
(6-12)\end{array}$ & $76,5 \pm 8,0 \mathrm{a}$ & $\begin{array}{c}27,7 \pm 0,1 \mathrm{e} \\
(25-38)\end{array}$ & $50,3 \mathrm{a}$ \\
\hline 30 & $\begin{array}{c}4,1 \pm 0,1 \mathrm{e} \\
(3-5)\end{array}$ & $90,5 \pm 8,4 \mathrm{a}$ & $\begin{array}{c}14,0 \pm 0,2 \mathrm{e} \\
(12-19)\end{array}$ & $71,0 \pm 5,5 \mathrm{a}$ & $\begin{array}{c}9,3 \pm 0,1 \mathrm{e} \\
(7-11)\end{array}$ & $77,5 \pm 6,8 \mathrm{a}$ & $\begin{array}{c}27,4 \pm 0,3 \mathrm{e} \\
(23-33)\end{array}$ & $49,8 \mathrm{a}$ \\
\hline 32 & $\begin{array}{c}3,8 \pm 0,1 \mathrm{f} \\
(3-5)\end{array}$ & $81,2 \pm 8,5 \mathrm{a}$ & $\begin{array}{c}16,6 \pm 0,3 d \\
(12-23)\end{array}$ & $48,0 \pm 5,1 b$ & $9,4 \pm 0,4 \mathrm{e}$ & $8,3 \pm 3,92 b$ & $\begin{array}{c}27,2 \pm 0,9 \text { e } \\
(925-31)\end{array}$ & $3,3 \mathrm{~b}$ \\
\hline
\end{tabular}

${ }^{a}$ Means followed by a common letter vertically do not differ significantly among themselves by Tukey test at the $5 \%$ probability level; values between parentheses indicate the variation interval.

${ }^{1}$ Data transformed to $\log (\mathrm{X}+0.5)$

${ }^{2}$ Data transformed to $\log (\mathrm{X}+2)$

${ }^{3}$ Data transformed to square root of $(X+3)$

level (CL) when 6 or more males were captured in one trap per week; and (5) installing one trap at every 10ha (3 to 3.5 thousand plants, depending on row spacing).

\section{RESULTS AFTER RELEASING THE PRODUCT IN THE MARKET}

Surveys conducted in citrus areas in the State of São Paulo and south of Minas Gerais using sex pheromone monitoring demonstrated that it is possible to significantly reduce fruit losses caused by the fruit borer. Losses with the use of this technology were, on average, 0.6 fruit/plant according to BENTO et al. (2001b), and 1.0 fruit/plant according to CARVALHO (2003) compared with 1 to 2 boxes (around 350 fruits per plant) without this strategy (Pinto 1994, 1995; Prates \& Pinto 1988a, b, 1991).

The synthetic product was commercially named Ferocitrus Furão ${ }^{\circledR}$, and was launched in October, 2001, being distributed through 17 stores of "Cooperativa dos Cafeicultores e Citricultores de São Paulo" (Coopercitrus - Coffee and Citrus Growers Cooperative) in the State of São Paulo.

The product, which includes a trap plus a tablet containing synthetic pheromone, costs about 7.0 dollars. Considering that a trap covers a citrus area of $10 \mathrm{ha}$, the product cost per hectare is equivalent to 0.7 dollar.

It is estimated, based on trap sales volumes and trap commercialization periodicity through the year, that this new management strategy is being used in at least $20 \%$ of the total area planted with citrus in the State of São Paulo and south of Minas Gerais throughout the year (PARRA, J.R.P et al.; data not published). Another important fact that resulted from this research is a mean estimate of reduction of at least $50 \%$ in the total volume of insecticides applied to control the fruit borer in the State of São Paulo (PARRA, J.R.P et al.; data not published).

More recently, results from weekly evaluations with the use of synthetic pheromone, during 2 years, allowed the period of occurrence of the pest to be correctly defined for different regions of the State of São Paulo and south of Minas Gerais (PARRA, J.R.P et al.; data not published). It was proven, for example, that the fruit borer is present throughout the year in all citrus-growing regions evaluated regardless of season, as long as there are fruits in the plants. It was thus demonstrated that an important correlation exists between the plant's phenology (presence of fruits) and the most favorable climatic conditions for the pest. In general, a larger E. aurantiana population occurs in spring, followed by summer or winter

Table V. Temperature threshold (Tb), thermal constant $(\mathrm{K})$ and coefficient of determination $\left(\mathrm{R}^{2}\right)$ of the different developmental periods of the citrus fruit borer, Ecdytolopha aurantiana, under laboratory conditions (GARCIA 1998).

\begin{tabular}{|c|c|c|c|c|}
\hline Period & $\begin{array}{c}\mathrm{Tb} \\
\left({ }^{\circ} \mathrm{C}\right)\end{array}$ & $\mathrm{CI}$ & $\begin{array}{c}\mathrm{K} \\
\text { (DD) }\end{array}$ & $\begin{array}{l}\mathrm{R}^{2} \\
(\%)\end{array}$ \\
\hline Embryonic & 10.06 & {$[9.79 ; 10.33]$} & 80.41 & 96.62 \\
\hline Larval & 9.79 & {$[9.78 ; 9.80]$} & 288.63 & 96.35 \\
\hline Pupal & 10.08 & {$[9.99 ; 10.18]$} & 179.24 & 96.36 \\
\hline Egg - adult & 9.15 & {$[6.77 ; 9.87]$} & 579.05 & 94.60 \\
\hline
\end{tabular}


Table VI. Fecundity, egg viability, and longevity of males and females of the citrus fruit borer, Ecdytolopha aurantiana under different relative humidities. Temperature, $27 \pm 2^{\circ} \mathrm{C}$; Photophase, 14 hours (Adapted from GARCIA 1998).

\begin{tabular}{|c|c|c|c|c|}
\hline \multirow[b]{2}{*}{$\begin{array}{l}\text { Humidity } \\
(\%)\end{array}$} & \multirow[b]{2}{*}{$\begin{array}{c}\text { Fecundity } \\
\text { (eggs/female) }\end{array}$} & \multirow[b]{2}{*}{$\begin{array}{c}\text { Egg } \\
\text { viability }\end{array}$} & \multicolumn{2}{|c|}{ Longevity (days) ${ }^{\mathrm{a}}$} \\
\hline & & & Males $^{\mathrm{b}}$ & Females $^{\mathrm{c}}$ \\
\hline 30 & 0.0 & 0.0 & $\begin{array}{c}5.0 \pm 0.3 \mathrm{c} \\
(3-10)\end{array}$ & $\begin{array}{c}6.5 \pm 0.34 c \\
(4-12)\end{array}$ \\
\hline 50 & 3.9 & 96.1 & $\begin{array}{c}9.3 \pm 0.8 b \\
(4-29)\end{array}$ & $\begin{array}{c}12.9 \pm 0.9 b \\
(4-27)\end{array}$ \\
\hline 70 & 34.1 & 96.0 & $\begin{array}{c}16.4 \pm 1.0 \mathrm{a} \\
(3-31)\end{array}$ & $\begin{array}{c}19.4 \pm 0.7 \mathrm{a} \\
(6-29)\end{array}$ \\
\hline 90 & 53.6 & 92.9 & $\begin{array}{c}14.9 \pm 0.4 a \\
(8-25)\end{array}$ & $\begin{array}{c}16.8 \pm 0.5 a \\
(11-24)\end{array}$ \\
\hline
\end{tabular}

${ }^{a}$ Means followed by a common letter vertically do not differ significantly among themselves by Tukey test at the $5 \%$ probability level; values between parentheses indicate the variation interval.

bData transformed to $\log (\mathrm{X}+0.5)$

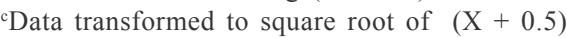

and, with less intensity, fall. The occurrence of a larger population in spring is possibly due to the abundance of ripe fruits, which culminates with the end of harvest in the 'Pera' variety and beginning of maturation in varieties 'Valência' and 'Natal'. During this season there is an increase in temperature and relative humidity (opening rains), which also favor the presence of the pest. In the fall, although there is still moisture in the soil (closing rains) and the minimum temperature is not very low, a smaller population could result from the lack of fruits at a suitable stage for the fruit borer's attack.

At some localities, the winter population of E. aurantiana was larger than in the summer. Much probably, a smaller availability of fruits occurs in the summer in these localities, because the harvest of late fruits of the 'Pera' variety is performed during that season, which are proportionally less in number than the main crop of the same variety in the winter (June to September).

\section{ONGOINGRESEARCHES AND NEW STRATEGIES}

New researches, including the installation of warning seasons for the entire state, in order to predict occurrence of the pest, as well as sex pheromone control techniques (sex confusion), are currently underway.

In addition, detailed studies on the influence of temperature and relative humidity on longevity, fertility, and fecundity of this pest will be conducted to define variable control levels for the different regions of the State of São Paulo and south of Minas Gerais.

\section{FINAL CONSIDERATIONS}

The E. aurantiana citrus fruit borer project, as a whole, from its basic biology to the development of a product used in the field, was obtained during 4-5 years, at an approximate cost of 50 thousand dollars (about $0.1 \%$ of the annual loss caused by the pest, of 50 million), generating intelectual patents for its members and several benefits for the citrus growers. Among the achieved benefits are worth mentioning: (i) a significant reduction in the loss of fruits attacked by the pest; (ii) a decrease in the number of sprays; (iii) maintenance of a higher number of natural enemies in the farm; and (iv) a reduction in labor needed to collect attacked fruits (picking) and samplings in the grove.

The type of program developed for the citrus fruit borer could serve as a model for other pests of agricultural importance in Brazil.

Acknowledgements. The authors express their thanks to Fundo de Defesa da Citricultura (Fundecitrus) for the financial support to the project; to Fundo de Amparo à Pesquisa do Estado de São Paulo (Fapesp), Conselho Nacional de Desenvolvimento Científico e Tecnológico (CNPq) and Coordenação de Aperfeiçoamento de Pessoal de Nível Superior (Capes) for the research scholarships granted during this period; to the producers and citrus companies which made their areas available for research; and to Cooperativa dos Cafeicultores e Citricultores de São Paulo for commercializing and advertising the product.

\section{REFERENCES}

Anonymous. 2000a. Cadeia produtiva de citros: Setor potencial. Revista da Fundecitrus 98: 7-9.

Anonymous. 2000b. Tecnologia contra o bicho-furão. Revista da Fundecitrus 96: 8-10.

Bento, J. M. S.; J. R. P. Parra; E. F. Vilela; J. M. Walder \& W. S. Leal. 2001a. Sexual behavior and diel activity of citrus borer moth Ecdytolopha aurantiana (Lepidoptera: Tortricidae). Journal of Chemical Ecology 27: 2053-2065.

Bento, J. M. S.; E. F. Vilela; J. R. P. Parra \& W. S. Leal. 2001 b. Monitoramento do bicho-furão com feromônio sexual: bases comportamentais para utilização dessa nova estratégia. Laranja 22: $351-366$.

Carvalho, D. R. 2003. Comparação de métodos de monitoramento e controle do bicho-furão, Ecdytolopha aurantiana (Lima, 1927) (Lepidoptera: Tortricidae), em citros. Dissertação de mestrado. Piracicaba, Escola Superior de Agricultura "Luiz de Queiroz", USP, 38 p.

Fennah, R. G. 1942. The "Orange Moth" of Dominica. Tropical Agriculture 19: 73-78.

Fnp Consultoria \& Comércio. 2001. Agrianual 2001: anuário da agricultura brasileira. São Paulo, 516 p.

Gallo, D.; O. Nakano; S. S. Neto; R. P. L. Carvalho; G. C. Batista; E. B. Filho; J. R. P. Parra; R. A. Zucchi; S. B. Alves \& J. D. Vendramim. 1988. Manual de entomologia agrícola. São Paulo, CERES, 649 p.

Garcia, M. S. 1998. Bioecologia e potencial de controle de Ecdytolopha aurantiana (Lima, 1927) (Lepidoptera: Tortricidae), o bicho-furão-dos citros, através de Trichogramma pretiosum Riley, 1879. Tese de doutorado. Piracicaba, Escola Superior de Agricultura "Luiz de Queiroz", USP, $118 \mathrm{p}$.

Garcia, M. S.; J. R. P. Parra; A. R. Rossi \& P. Kasten JR. 1998. Bioecologia do bicho-furão e perspectivas de controle. Laranja 19: 249-260.

Garcia, M. S. \& J. R. P. Parra. 1999. Comparação de dietas artificiais, com fontes proteicas variáveis, para a criação de Ecdytolopha aurantiana (Lima) (Lepidoptera: Tortricidae). Anais da Sociedade 
Entomológica do Brasil 28: 219-232.

Gravena, S. 1998. Manejo ecológico de pragas dos citros - aspectos práticos. Laranja 19: 61-77.

Leal, W. S.; J. M. S. Bento; Y. Murata, M. Ono; J. R. P. Parra \& E. F. VILELA. 2001. Identification, synthesis, and field evaluation of the sex pheromone of the citrus fruit borer Ecdytolopha aurantiana. Journal of Chemical Ecology 27: 2041-2051.

Meyrick, E. 1931. Exotic Microlepidoptera 4: 129-160.

Molina, R. M. S. 2003. Bioecologia de duas espécies de Trichogramma para o controle de Ecdytolopha aurantiana (Lima, 1927) (Lepidoptera: Tortricidae) em citros. Dissertação de mestrado. Piracicaba, Escola Superior de Agricultura "Luiz de Queiroz", USP, $80 \mathrm{p}$.

Nakano, O. \& M. G. Soares. 1995. Bicho-furão: Biologia, hábitos e controle. Laranja 16: 209-221.

Parra, J. R. P.; P. Kasten JR.; R. M. S. Molina \& M. L. Haddad. $2001 \mathrm{a}$. Efeito do pH no desenvolvimento do bicho-furão. Laranja 22: 321-332.

Parra, J. R. P.; O. Nakano; J. M. S. Bento \& M. S. Garcia. 2001 b. Manual de Manejo do Bicho Furão. Araraquara, Fundecitrus, $10 \mathrm{p}$.

Parra, J. R. P.; H. N. Oliveira \& A. S. Pinto. 2003. Guia ilustrado de pragas e insetos benéficos dos citros. Piracicaba, $140 \mathrm{p}$.

PINTO, W. B. DE S. 1994. "Bicho-furão" considerado hoje uma das principais pragas da nossa citricultura. Laranja \& Cia 38: 4-5.

PinTo, W. B. DE S. 1995. Mariposa-da-laranja ou bicho-furão: Uma praga que está aumentando na citricultura paulista. Laranja 16: 243-250.

Prates, H. S. \& W. B. DE S. Pinto. 1988a. Bicho furão - Gymnandrosoma aurantianum Lima, 1927. Novos surtos da mariposa-daslaranjas. Campinas, CATI, 1988a 4 p. (CATI, Informativo Técnico).

Prates, H. S. \& W. B. de S. Pinto. 1988b. Ocorrência da mariposa das laranjas (Gymnandrosoma aurantianum Lima, 1927) na citricultura paulista. Laranja 9: 117-124.

Prates, H. S. \& W. B. De S. Pinto. 1991. Controle do "bicho-furão" na citricultura. Informativo Coopercitrus 60: 18-24.

Schultz, E. T. 1939. La mariposa de los naranjos (Gymnandrosoma sp.). Revista Industrial Agricultura 29: 87-90.

Silva, A. G. A.; C. R. Gonçalves; D. M. Galvão; A. J. L. Gonçalves; J. Gomes; M. N. Silva \& L. DE Simoni. 1968. Quarto catálogo dos insetos que vivem nas plantas do Brasil: seus parasitos e predadores. v. 2, pt. 1: Insetos do Brasil: hospedeiros e inimigos naturais. Rio de Janeiro, Ministério da Agricultura; 622 p.

White, G. L. 1999. Sapindus saponaria L. (Sapindaceae), a new host of Ecdytolopha aurantianum (Lima) (Lepidoptera: Tortricidae: Olethreutinae). International Journal of Pest Management 45: 287-291.

White, G. L. \& K. Tuck 1993. Outbreak of Ecdytolopha aurantianum (Lima) on citrus in Trinidad. FAO-Plant-Protection-Bulletin 41: $130-132$ 